\title{
Pest Evaluation in Sustainable Cabbage Production Systems
}

\author{
G.D. Hoyt ${ }^{1}$ and J.F. Walgenbach ${ }^{2}$ \\ Mountain Horticultural Crops Research and Extension Center, 2016 Fanning \\ Bridge Road, Fletcher, NC 28732
}

Additional index words. strip-till, relay intercropping, organic, weed control, lepidoptera, alternaria leaf spot, Brassica oleracea

\begin{abstract}
Conservation tillage systems provide optimum conditions to reduce soil erosion and increase surface soil organic matter. This experiment was established with the longterm goal of developing conservation tillage systems that use either chemical inputs to produce vegetables and control pests, or legume cover crops, biological pesticides, and tillage to provide plant nutrition and control pests. The experiment consisted of cabbage (Brassica oleracea var. L. Capitata Group) grown by traditional-tillage (TT) or striptillage (ST) culture using either chemical or organic production methods for pest control. Cabbage heads were heavier with TT than with ST for the chemical production system. Although weed biomass was significantly higher with organic methods, there was a poor relationship between weed biomass at harvest and cabbage head weight. The lack of differences in lepidopterous pest damage suggests that the conservation tillage systems examined likely would not affect lepidopterous pest management systems using biological insecticides. Within tillage treatments, the organic production system resulted in less Alternaria infection than did the chemical production system. Since no fungicides were applied on any treatment, lower disease ratings in the organic production system may have been the result of reduced soil contact of the cabbage leaves from the increased soil coverage by the weed and intercropped legume canopy.
\end{abstract}

Conservation tillage can be an important component of sustainable vegetable production systems (Fretz et al., 1993). Most vegetables grown under conservation tillage produce yields similar to those of traditionaltillage (TT) systems (Coolman and Hoyt, 1993a). However, yield reductions have been reported for short-season vegetable crops or crops planted in early spring when large amounts of crop residue in conservation tillage slows soil warming (Bellinder et al., 1987; Hoyt and Konsler, 1988; McKeown et al., 1988; Petersen et al., 1986). In addition, vegetable plant disease presence can be influenced by conservation tillage practices that leave excessive residues on the soil surface, providing a means for pathogens to overwinter, with many diseases increasing without proper crop rotation (Sumner et al., 1986).

Major obstacles for implementation of organic agriculture include nutrient manage-

\footnotetext{
Received for publication 21 Nov. 1994. Accepted for publication 28 Mar. 1995. The use of trade names in this publication does not imply endorsement by the North Carolina Agricultural Research Service or Cooperative Extension Service, nor criticism of similar ones not mentioned. Appreciation is given to Paul B. Shoemaker, professor and extension plant pathologist, North Carolina State Univ., for alternaria leaf spot ratings. The cost of publishing this paper was defrayed in part by the payment of page charges. Under postal regulations, this paper therefore must be hereby marked advertisement solely to indicate this fact.

${ }^{1}$ Associate Professor. Dept. of Soil Science, North Carolina State Univ.

${ }^{2}$ Associate Professor. Dept. of Entomology, North
} Carolina State Univ. ment, weed control, insect control, and disease prevention. Traditional organic agriculture often uses summer legume intercropping systems and winter cover crops to increase nutrient recycling and $\mathrm{N}$ input through biological $\mathrm{N}$ fixation (Coolman and Hoyt, 1993b; Lowrance, 1990; Stivers and Shennan, 1991; Vandermeer, 1989). Although availability of legume-based $\mathrm{N}$ may be unpredictable due to complex soil microbial decomposition, most systems accumulate $\mathrm{N}$ and other nutrients and increase productivity with time (Groffman et al., 1987; Hoyt and Hargrove, 1986). Organic agriculture often uses spring cultivation, mechanical weed control during the summer, and biologically based insecticides as standard practices to control pests. Many of these same control methods can be used in conservation-tillage organic systems. For instance, flail chopping a winter legume cover crop can replace burndown herbicides, and surface mechanical weed control (single-row sickle bar or string-type mower) for between-row cultivation can replace pre- and postemergence herbicides. Biologically based insecticides are sometimes effective replacements for synthetic insecticides for insect pests in conservation-tilled systems, but biological fungicides are currently not available.

This experiment was established with the long-term goal of developing conservation tillage systems that use either chemical management systems to produce vegetables and control pests, or legume cover crops, biological insecticides, and tillage to provide plant nutrition and control pests. This paper discusses the differences in insect, disease, and weed control related to different tillage systems in cabbage.
The experiment was established at the Mountain Horticultural Crops Research Station, Fletcher, N.C., on a Delanco loam soil (fine-loamy, mixed, mesic Aquic Hapludults). Sweet corn (Zea mays L.) was established in 1992 as the first of three vegetables [sweet corn, cabbage, and tomatoes (Lycopersicon esculentum Mill.)] grown in rotation (one crop per year).

Cabbage was grown in 1993 (second year) in this long-term vegetable rotation experiment. The four production systems (Table 1) compared were as follows:

Traditional-till-chemical (TT-C). A fallplanted cover crop of rye (Secale cereale L.) was flail-chopped, moldboard-plowed, and disked during the week before transplanting. Ammonium nitrate fertilizer was applied at $125 \mathrm{~kg} \mathrm{~N} / \mathrm{ha}$ in a band and incorporated in-row before transplanting. For weed control, $\mathrm{N}, \mathrm{N}$ diethyl-2-(1-naphthalenyloxy)-propionamide (napropamide) [Devrinol 50 DF (ICI Americas, Wilmington, Del.)] at $1.12 \mathrm{~kg}$ a.i./ha was applied over the entire plot and 2-chloro-1-(3ethoxy-4-nitrophenoxy)-4-(trifluoromethyl) benzene (oxyfluorfen) [Goal 1.6 EC (Rohm and Haas Co., Philadelphia)] at $0.34 \mathrm{~kg}$ a.i./ha was applied between rows on 10 June.

Traditional-till-organic (TT-O). A fallplanted cover crop of hairy vetch (Vicia villosa Roth) was flail-chopped, moldboard-plowed, and disked during the week before planting. Soybean (Glycine max L. Merr.) meal (chemical analysis of $7 \% \mathrm{~N}$ ) was applied at $125 \mathrm{~kg} \mathrm{~N} /$ ha pretransplant and incorporated in-row. No herbicides were applied, but two between-row cultivations were made before 11 July 1993, when red clover (Trifolium pratense L.) seed $\left(20 \mathrm{~kg} \cdot \mathrm{ha}^{-1}\right)$ was relay-intercropped between cabbage rows.

Strip-till-chemical $(S T-C)$. A fall-planted cover crop of rye was chemically killed with glyphosate (Roundup 4L; Monsanto Co., St. Louis) at $2.24 \mathrm{~kg}$ a.i./ha on 28 May 1993 and strip-tilled using a Bush Hog Ro-till (Bush Hog Corp., Selma, Ala.) on 31 May 1993. Strip-tillage created a narrow band of cultivated soil $40 \mathrm{~cm}$ wide, with cover crop residue maintained between rows spaced $100 \mathrm{~cm}$ apart (Hoyt et al., 1994). Ammonium nitrate fertilizer was applied at $125 \mathrm{~kg} \mathrm{~N} /$ ha pretransplant and incorporated within the strip-tilled area. Weed control was the same as for TT-C.

Strip-till-organic $(S T-O)$. A relay intercropped cover crop of crimson clover [Trifolium incarnatum (L.) 'Tibbee'] (planted in the previous crop of sweet corn on 22 June 1992) was flail-chopped on 27 May 1993 and striptilled similar to ST-C on 31 May 1993. As in TT-O, soybean meal was incorporated at the rate of $125 \mathrm{~kg} \mathrm{~N} / \mathrm{ha}$. No herbicides were applied, but weeds were mowed near the soil surface with a string-type mower on 28 July 1993.

Plant material. Cabbage ('Rio Verde') seedlings (10 to $15 \mathrm{~cm}$ high with four true leaves) were hand-transplanted on 4 June into plots consisting of five double rows of cabbage. Double rows were spaced $40 \mathrm{~cm}$ apart 
Table 1. Treatments for the cabbage production season.

\begin{tabular}{|c|c|c|c|c|c|}
\hline \multirow{2}{*}{$\begin{array}{l}\text { Tillage } \\
\text { system }\end{array}$} & \multirow{2}{*}{$\begin{array}{l}\text { Production } \\
\text { system }\end{array}$} & \multicolumn{2}{|c|}{ Cover crop } & \multirow{2}{*}{$\begin{array}{c}\mathrm{N} \text { fertilizer } \\
(125 \mathrm{~kg} \mathrm{~N} / \mathrm{ha})\end{array}$} & \multirow{2}{*}{$\begin{array}{l}\text { Weed } \\
\text { control }\end{array}$} \\
\hline & & Crop & Kill method & & \\
\hline \multirow[t]{2}{*}{ Traditional } & Chemical & Rye & $\begin{array}{l}\text { Flail-chopped, } \\
\text { plowed, and disked }\end{array}$ & $\mathrm{NH}_{4} \mathrm{NO}_{3}$ & $\begin{array}{l}\text { Napropamide and } \\
\text { oxyfluorfen }\end{array}$ \\
\hline & Organic & Hairy vetch & $\begin{array}{l}\text { Flail-chopped, } \\
\text { plowed, and disked }\end{array}$ & $\begin{array}{l}\text { Soybean } \\
\text { meal }\end{array}$ & $\begin{array}{l}\text { Two between-row } \\
\text { cultivations before } \\
11 \text { July }\end{array}$ \\
\hline \multirow[t]{2}{*}{ Strip-till } & Chemical & Rye & $\begin{array}{l}\text { Glyphosate and } \\
\text { strip-tillage }\end{array}$ & $\mathrm{NH}_{4} \mathrm{NO}_{3}$ & $\begin{array}{l}\text { Napropamide and } \\
\text { oxyfluorfen }\end{array}$ \\
\hline & Organic & $\begin{array}{l}\text { Crimson } \\
\text { clover }\end{array}$ & $\begin{array}{l}\text { Flail-chopped and } \\
\text { strip-tillage }\end{array}$ & $\begin{array}{l}\text { Soybean } \\
\text { meal }\end{array}$ & $\begin{array}{l}\text { Mowed with string- } \\
\text { type mower on } \\
28 \text { July }\end{array}$ \\
\hline
\end{tabular}

${ }^{2}$ Bacillus thuringiensis was used for insect control in all systems.

(30 $\mathrm{cm}$ within row) and each set of double rows was spaced $1 \mathrm{~m}$ apart. All plots were $8 \mathrm{~m}$ wide and $14 \mathrm{~m}$ long, with a final population of 47,620 plants/ha for all treatments. Treatments were arranged in a randomized complete-block (RCB) design with four replications. Irrigation $\left(25 \mathrm{~mm} \cdot \mathrm{ha}^{-1}\right.$ on $5,7,10,17$, and 25 June) was applied only to establish transplants during June (rainfall was $27 \mathrm{~mm}$ in June). Bacillus thuringiensis var. kurstaki (BiobitFC; DuPont Agricultural Products, Wilmington, Del.) was applied at 3.5 liters.ha ${ }^{-1}$ over the entire experimental area at weekly intervals beginning on 16 June and continued up to 1 week before harvest (17 Aug. 1993). At harvest, 20 heads per treatment were evaluated visually for insect damage by evaluating each plant on a scale where $0=$ no damage, $1=$ frame leaf damage, $2=$ minimal wrapper leaf damage, 3 $=$ extensive wrapper leaf damage, $4=$ head damage, and $5=$ severe head damage. No bactericide/fungicide was applied during the growing season. Heads were evaluated subjectively for severity of alternaria leaf spot [Alternaria brassicae (Berk.) Sacc.] 3 days before harvest on a scale where $0=$ no disease, $1=$ trace, $2=$ light, $3=$ moderate, $4=$ heavy, and $5=$ severe damage to wrapper leaves. Weed biomass was sampled near the middle of each plot from a $1-\mathrm{m}^{2}$ area between cabbage rows and oven-dried at $65 \mathrm{C}$ for 4 days. Statistical analyses were performed using the SAS GLM statistical program with means separated by LSD (SAS Institute, 1985).

\section{Results and Discussion}

Weeds. Through the midseason sampling period ( 23 July) weeds were not present in TT or ST where herbicides were applied, but were present in both tillage systems of the organic production systems. The TT-O plots were mechanically cultivated twice before the 23 July biomass measurement and, therefore, contained only a few small weeds [common purslane (Portulacaoleracea L.)] in-row. Thus, biomass was not measured for this treatment at this time. With ST-O, which had only the flailchopped crimson clover residue to reduce weed populations, weed control was limited to areas with a thick residue. Average dry weight weed biomass measured on 23 July for ST-O was $1510 \pm 590 \mathrm{~kg} \cdot \mathrm{ha}^{-1}$. Weed species in this treatment consisted of common purslane, hairy galinsoga [Galinsoga ciliata (Raf.) Blake], redroot pigweed (Amaranthus retroflexus L.), and Pennsylvania smartweed (Polygonum pensylvanicum L.). Weeds were mowed with a string-type mower after weed biomass had been measured.

Weed biomass at harvest (27 Aug.) reflected the reduced efficiency of weed control for all production systems late in the growing season (Table 2). Hairy galinsoga, redroot pigweed, and yellow nutsedge (Cyperus esculentus L.) were the most prevalent weed species in the chemical production systems, although weeds were most intense in the organic production systems (Table 2); the dominant weed species in these were common purslane, hairy galinsoga, redroot pigweed, Pennsylvania smartweed, and fall panicum (Panicum dichotomiflorum Michx.).

Insect damage. Insect damage was minimal in this study (Table 2). On untreated cabbage planted adjacent to this experiment, cabbage looper [Trichoplusia ni (Hubner)], imported cabbageworm [Artogeia rapae(L.)], and diamondback moth [Plutella xylostella (L.)] were the only insect pests identified. Cabbage looper was most abundant, with an average of 4.1 larvae/head, resulting in $100 \%$ of these heads being unmarketable. The lack of statistical differences in lepidopterous insect damage suggests that CT will not adversely affect a cabbage insect management system using Bacillus thuringiensis. This contention is further supported by the findings of Roberts and Cartwright (1991), who reported that cabbage looper populations were slightly lower on cabbage grown in a standing cover of rye relative to that grown on bare soil.

Disease rating. Overall, the fungus Alternaria brassicae was not considered a disease threat to the cabbage and no fungicides were applied. Alternaria developed late in the growing season and damage was restricted to the outer wrapper leaves, which did not affect the marketability of the heads (Table 2). There was a trend toward a higher incidence of Alternaria infection in ST cabbage compared with the TT system within each production system. Higher incidence of bacterial diseases on vegetables have been reported with conservation tillage than with TT (McKeown et al., 1988; Sumner et al., 1981). With TT, the organic production system received a lower Alternaria infection rating than did the chemical production system. This difference may be related to the bare soil maintained for TT-C compared to the residues and weeds in the TT-O. Alternaria can be distributed by soil particle movement from raindrop splash. In both organic systems, intercropped legumes and weeds existed between cabbage crop rows, potentially protecting the plants from raindrop splash and thus reducing Alternaria movement onto the cabbage leaves.

Yield. The TT-C system produced heavier heads than the ST-C system (Table 2). Cabbage transplanted into the ST plots were set in double rows at the edge of each side of the tilled area, which resulted in the establishment of roots in a shallow cultivated area (the middle of the strip was cultivated the deepest by the subsoil shank, while on each side of the subsoil shank, two shallow disks cultivated the soil). This procedure may have delayed root development and reduced plant growth. The experiment was established in a Delanco series soil, which is easily compacted and requires tillage to reduce compaction. Cabbage yield results may reflect the influence that soil physical characteristics play in root development (Morse, 1993). Previous research has shown lower corn yields with no till on finetextured soils, with yield reductions attributed to wheel-induced compaction (Voorhees and Lindstrom, 1983). Knavel and Herron (1981) also suggested cabbage root impedance and restricted growth in no-tillage treatments on a Maury silt loam soil in Kentucky. Soil temperatures also have been shown to be lower in strip-till and no-till culture compared with conventional tillage (Hoyt and Konsler, 1988), which may have affected early plant growth and delayed maturity.

Weed, disease, and insect pests did not appear to be the overriding factor affecting cabbage yield or quality in any of the production systems examined. Although weed biomass was significantly higher in the organic systems, there was a poor relationship between weed biomass at harvest and cabbage head weight. Similarly, although alternaria leaf spot was more intense in herbicide-treated plots that had less surface residue, infection was confined to the outer wrapper leaves and did not affect yields. Tillage systems, however, did significantly affect yields as measured by cabbage head weight, with yields in the ST system lower than in TT.

We attribute reduced yields in the ST system to the use of double rows in which plant roots were established in a shallow cultivated area, and to poor soil structure associated with the Delanco soil series. Logan et al. (1991) reviewed the changes in physical properties of soils cropped under conservation tillage and found that yields were suppressed in soils prone to compaction due to vehicular traffic. They further stated that a transition period of 3 to 5 years is necessary for crop yields to stabilize. Hargrove et al. (1982) and Radcliff et al. (1988) in Georgia also have concluded that transitional periods of a few years are necessary to realize the benefits of improved soil structure and greater water infiltration when switching from traditional to conservation tillage systems. 
Table 2. Weed biomass, lepidopterous pest damage, marketable heads, alternaria leaf spot damage, and head weights of cabbage grown under four tillage/production systems.

\begin{tabular}{llccccc}
\hline $\begin{array}{l}\text { Tillage } \\
\text { system }\end{array}$ & $\begin{array}{c}\text { Production } \\
\text { system }\end{array}$ & $\begin{array}{c}\text { Weed biomass } \\
\text { at harvest }\left(\mathrm{kg} \cdot \mathrm{ha}^{-1}\right)\end{array}$ & $\begin{array}{c}\text { Lepidopterous } \\
(\text { damage rating) }\end{array}$ & $\begin{array}{c}\text { Marketable } \\
\text { heads }(\%)\end{array}$ & $\begin{array}{c}\text { Alternaria leaf spot } \\
(\text { damage rating) }\end{array}$ & $\begin{array}{c}\text { Cabbage wt }^{\mathrm{w}} \\
(\mathrm{kg} / \mathrm{head})\end{array}$ \\
\hline Traditional & Organic & 1265 & 1.4 & 90 & 2.7 & 0.80 \\
& Chemical & 213 & 1.3 & 95 & 4.0 \\
Strip-till & Organic & 1178 & 1.4 & 95 & 3.2 & 0.92 \\
& Chemical & 422 & 1.4 & 93 & 4.4 & 0.52 \\
LSD $_{(0.05)}$ & & 543 & NS & NS & 1.1 & 0.57 \\
\hline
\end{tabular}

${ }^{2}$ Weed biomass measurements (1-m² sample per plot) as dry weight after harvest on 27 Aug.

${ }^{y}$ For insect damage ratings, 20 heads per treatment were rated on a scale: $0=$ no damage, $1=$ frame leaf damage, $2=$ minimal wrapper leaf damage, $3=$ extensive wrapper leaf damage, $4=$ head damage, and $5=$ extensive damage. Heads receiving a rating of $\leq 2$ were considered marketable.

'Disease damage ratings: $0=$ no disease, $1=$ trace, $2=$ light, $3=$ moderate, $4=$ heavy, and $5=$ severe damage to wrapper leaves due to alternaria leaf spot. No noticeable damage was found on the marketable portion of the cabbage heads for any treatments.

\section{Literature Cited}

Bellinder, R.R., H.P. Wilson, and T.E. Hines. 1987. Comparative studies of conventional and notillage systems for snap bean production. HortScience 22:159.

Coolman, R.M. and G.D. Hoyt. 1993a. The effects of reduced tillage on the soil environment. HortTechnology 3:143-145.

Coolman, R.M. and G.D. Hoyt. 1993b. Increasing sustainability by intercropping. HortTechnology 3:309-312.

Fretz, T.A., D.R. Keeney, and S.B. Sterrett. 1993. Sustainability: Defining the new paradigm. HortTechnology 3:118-126.

Groffman, P.M., P. Hendrix, and D.A. Crossley. 1987. Nitrogen dynamics in conventional and notillage agroecosystems with inorganic fertilizer or legume nitrogen inputs. Plant Soil 97:315-332.

Hargrove, W.L., J.T. Reid, J.T. Touchton, and R.N. Gallaher. 1982. Influence of tillage practices on the fertility status of an acid soil double-cropped to wheat and soybeans. Agron. J. 74:684-687.

Hoyt, G.D. and W.L. Hargrove. 1986. Legume cover crops for improving crop and soil management in the southern United States. HortScience 21:397-402.

Hoyt, G.D. and T.R. Konsler. 1988. Soil water and temperature regimes under tillage and cover crop management for vegetable culture, p. 697 702. Proc. 11th Intl. Conf., Internation Soil Tillage Res. Organization, Edinburgh, Scotland.

Hoyt, G.D., D.W. Monks, and T.J. Monaco. 1994. Conservation tillage for vegetable production. HortTechnology 4:129-135.

Knavel, D.E. and J.W. Herron. 1981. Influence of tillage system, plant spacing, and nitrogen on head weight, yield, and nutrient concentration of spring cabbage. J. Amer. Soc. Hort. Sci. 106:540-545.

Logan, T.J., R. Lal, and W.A. Dick. 1991. Tillage systems and soil properties in North America. Soil \& Tillage Res. 20:241-270.

Lowrance, R. 1990. Research approaches for ecological sustainability. J. Soil \& Water Conservation 45:51-54.

McKeown, A.W., R.F. Cerkauskas, and J.W. Potter. 1988. Influence of strip tillage on yield, diseases, and nematodes of tomatoes. J. Amer. Soc. Hort. Sci. 113:328-331.

Morse, R.D. 1993. Components of sustainable production systems for vegetables - Conserving soil moisture. HortTechnology 3:211-214.

Petersen, K.L., H.J. Mack, and D.E. Booster. 1986. Effect of tillage on sweet corn development and yield. J. Amer. Soc. Hort. Sci. 111:39-42.
Radcliffe, D.E., E.W. Tollner, W.L. Hargrove, R.L. Clark, and M.H. Golabi. 1988. Effect of tillage practices on infiltration and soil strength of a Typic Hapludult soil after 10 years. Soil Sci. Soc. Amer. J. 52:798-804.

Roberts, B.W. and B. Cartwright. 1991. Alternative soil and pest management practices for sustainable production of fresh-market cabbage. J. Sustainable Agr. 1:21-35.

SAS Institute. 1985. SAS user's guide: Statistics. 5th ed. SAS Inst., Cary, N.C.

Stivers, L.J. and C. Shennan. 1991. Meeting the nitrogen needs of processing tomatoes through winter cover cropping. J. Prod. Agr. 4:330-335.

Sumner, D.R., B. Doupnik, Jr., and M.G. Boosalis. 1981. Effects of reduced tillage and multiplecropping on plant diseases. Annu. Rev. Phytopathol. 19:167-187.

Sumner, D.R., E.D. Threadgill, D.A. Smittle, S.C. Phatak, and A.W. Johnson. 1986. Conservation tillage and vegetable diseases. Plant Dis. 70(10):906-911.

Vandermeer, J. 1989. The ecology of intercropping. Cambridge Univ. Press, Cambridge, U.K.

Voorhees, W.B. and M.J. Lindstrom. 1983. Soil compaction constraints on conservation tillage in the northern Corn Belt. J. Soil \& Water Conservation 38(3):307-311. 